\title{
PENGARUH PERLAKUAN TEMPERATUR PEMANASAN PADA HASIL PENGELASAN METODE SMAW TERHADAP HARDNESS LOGAM INDUK DAN LOGAM LAS
}

\author{
Helanianto $^{1}$ \\ ${ }^{1}$ Dosen Jurusan Teknik Mesin Politeknik Negeri Ketapang \\ Jurusan Teknik Mesin, Politeknik Negeri Ketapang \\ J1. Rangga Sentap, Dalong, Sukaharja, Delta Pawan, Ketapang, Kalimantan Barat, Indonesia 78812 \\ Email : helanianto@yahoo.com
}

\begin{abstract}
Abstrak. Pengelasan merupakan salah satu unsur penting dalam dunia konstruksi modern yang berkaitan dengan penyambungan dua part logam atau lebih, sehingga satu dan mempunyai kekuatan setara logam induknya. Dan dengan metode-metode yang dilakukan, perlakuan pada logam tersebut memberikan dampak pada kekuatan. Kekuatan inilah yang menjadi tujuan utama setiap pengguna ataupun konsumen, agar konstruksi yang mereka bangun bisa bertahan lama dari pengaruh fenomena alam. Penelitian ini bertujuan untuk mengetahui pengaruh perlakuan fisis logam, yakni heattreatment pada proses pengelasan logam terhadap kekerasan yang terbentuk. Dan untuk mencapai target penelitian maka dilakukan eksperimen pada material dengan metode pengelasan SMAW dan heattreatment pasca pengelasan. Hasil penelitian ini di validasi dengan dukungan metode uji material hardness test. Hasil penelitian ini menunjukkan kekerasan raw material uji sebesar 51.4 HRB, heattreatment logam las pada temperatur $900^{\circ} \mathrm{C}$ memiliki nilai kekerasan 54.3 HRB dan HAZ 52.7 HRB, pada temperatur heattreatment $800^{\circ} \mathrm{C}$ kekerasan logam las $52.6 \mathrm{HRB}$ dan HAZ $52 \mathrm{HRB}$, sedangkan pada heattreatment $700^{\circ} \mathrm{C}$ kekerasan logam las $48.2 \mathrm{HRB}$ dan HAZ 51.4 HRB. Dengan demikian, hasil ini menunjukan bahwa peningkatan temperatur heattreatment menyebabkan perbedaan temperatur pada proses pendinginan semakin besar sehingga yang terjadi adalah kecenderungan pendinginan cepat; pendinginan cepat tersebut menyebabkan kekerasan material semakin meningkat.
\end{abstract}

\section{Keywords: Pengelasan SMAW, Perlakuan Panas, Kekerasan Material}

\begin{abstract}
Welding is one important element in the world of modern construction related to connecting two or more metal parts, so that one and have the strength of the parent metal equivalent. And with methods that do, treatment of these metals have an impact on the power. The strength of which is the main objective of every user or consumer, so that their construction could last a long wake of the influence of natural phenomena. This study aims to determine the effect of treatment of physical metal, the metal welding process heattreatment on the violence that is formed. And to achieve the target of the research, conducted experiments on material with SMAW welding methods and post-weld heattreatment. The results of this study validated test methods support material hardness test. The results of this study indicate raw material hardness test of 51.4 HRB, heattreatment weld metal at a temperature of 900C has a hardness value 54.352 .7 HRB HRB and HAZ, at a temperature of $800 \mathrm{C}$ heattreatment $52.6 \mathrm{HRB}$ hardness of weld metal and $\mathrm{HAZ} 52 \mathrm{HRB}$, whereas the heattreatment $700{ }^{\circ} \mathrm{C}$ hardness weld metal and HAZ 51.448 .2 HRB HRB. Thus, these results show that an increase in temperature heattreatment causes temperature differences on the greater the cooling process so that there is the tendency of rapid cooling; The rapid cooling led to increased material hardness.
\end{abstract}

Keywords: SMAW Welding, Heat Treatment, The Material Hardness

\section{Pendahuluan}

Perkembangan teknologi dibidang konstruksi yang melibatkan material logam dari tahun ke tahun semakin meningkat seiring permintaan konsumen yang membutuhkan kekuatan dan kehandalan. Salah satu teknologi yang berkaitan erat dengan masalah konstruksi tersebut adalah teknologi pengelasan logam, dimana teknik penyambungan ini dikenal luas karena efisien dan mudah diaplikasikan.

Beberapa contoh aplikasi pengelasan tersebut antaralain; pembuatan rangka baja, konstruksi perkapalan, bejana tekan, konstruksi jembatan, sarana transportasi, rel, pipa saluran dan lain sebagainya. Selanjutnya prosedur pengelasan yang 
baik akan memberikan hasil yang baik pula bila sebelumnya telah dibuat rencana tentang jadwal pembuatan, proses pembuatan, alat-alat yang diperlukan, bahan-bahan, urutan pelaksanaan, persiapan pengelasan, perlakuan setelah pengelasan, pengaturan pekerjaan dan lain-lainnya (Wiryosumarto et al, 2008).

Sedangkan langkah-langkah yang dilakukan untuk meningkatkan strength dan toughness dalam pengelasan antara lain: dengan pengaturan heat input, penambahan ataupun pengurangan komposisi unsur, memberi perlakuan panas sebelum dan sesudah pengelasan. Selain itu, pertimbangan terhadap pengaruh kondisi lingkungan sekitar pada saat pengelasan juga perlu dilakukan untuk meningkatkan kualitas hasil pengelasan (Widharto, 2008).

Beberapa penelitian yang terkait dengan pengelasan logam ini antaralain; Poorhaydari et al (2005), dengan analisa pemodelan-Estimasi laju pendinginan pada plat tebal dan tipis. Paradowska et al (2006), dengan menggunakan metode teknik Neutron Diffraction (ND) diperoleh hasil penelitian bahwa heat input yang sangat tinggi akan memperlambat laju pendinginan. Armentani et al (2007), Dengan metode Finite Element Analysis (FEA) diperoleh hasil penelitian sebagai berikut: distribusi temperatur transient pada suatu sambungan las sangat dipengaruhi oleh konduktivitas termal, variasi temperatur versus efisiensi yang mempunyai tendensi sama.

Selanjutnya Budiarsa (2008), Dengan menggunakan metode Eksperimen Faktorial diperoleh hasil penelitian: besar arus dan kecepatan volume aliran gas pelindung pada las GMAW memberikan pengaruh terhadap ketangguhan HAZ. Picarima et al (2009), Dengan metode pengamatan secara mikro (SEM) dan makro pada mekanisme pendinginan paksa hasil pengelasan TIG baja tahan karat 304 diperoleh: semakin tinggi arus yang diberikan maka prosentase karbida khrom menurun, semakin jauh jarak penyemprotan media pendingin maka prosentase karbida semakin bertambah. Untuk lebar HAZ yang terbentuk diperoleh fenomena: semakin dekat jarak penyemprotan media pendingin maka lebar HAZ semakin berkurang dan semakin jauh jarak penyemprotan media pendingin maka lebar HAZ yang terbentuk semakin bertambah.

Berkenaan dengan beberapa penelitian diatas, salah satu kasus yang akan diangkat pada penelitian ini adalah metode hettreatment pasca pengelasan, yang diduga akan mempengaruhi sifat mekanik logam induk dan logam las; untuk itu maka dirasa perlu dilakukan penelitian lebih lanjut mengenai sifat mekanik logam pasca pengelasan dengan penerapan metode heattreatment. Dan sebagai respon terhadap permasalahan tersebut maka diambilah sebuah judul penelitian "Pengaruh perlakuan temperatur pemanasan pada hasil pengelasan metode SMAW terhadap hardness logam induk dan logam las".

\section{Metode Penelitian}

Pengetahuan masyarakat pengguna tentang kekuatan material merupakan daya topang pembangunan infrastruktur yang baik dan berkualitas. Hal tersebut masih menjadi masalah yang harus ditekankan dan dimasyarakatkan, mengingat keberadaan konstruksi yang kurang menjamin keselamatan akan mengancam jiwa secara kasat mata tanpa diketahui kapan akan terjadi.

Dalam kehidupan sehari-hari kadangkala kita saksikan bagaimana orang melaksanakan pembangunan suatu konstruksi dengan alatperalatan yang baik. Namun ternyata dibalik itu alat dan peralatan bukanlah hal yang dianggap cukup untuk membangun suatu konstruksi yang baik, namun perlu dibekali pengetahuan mengenai teknik-teknik dalam proses pengerjaan sehingga tujuan konstruksi yang handal bisa tercapai.

Dalam hal pengelasan logam, selain teknik pengelasan yang baik juga ditambahkan pengetahuan tentang perlakuan logam pra ataupun pasca pengelasan. Dimana fungsinya adalah untuk mendukung proses dan hasil dari pengelasan yang dilaksanakan.

Berkaitan dengan hal tersebut, yang menjadi sorotan dalam penelitian adalah perlakuan panas atau heattreatment pasca pengelasan. Dimana teknik ini akan menetralisir tegangan yang terjadi akibat proses pengelasan atau yang lajim disebut tegangan termal, dan dengan penetralisiran ini diharapkan konstruksi menjadi stabil sehingga memperkecil terjadinya pemicu kerusakan.

Langkah-langkah yang dilakukan adalah mempersiapkan bahan sebagai specimen yakni plat baja karbon rendah (low carbon steel) yang dipotong persegi panjang. Plat tersebut dipersiapkan untuk tahap pengelasan dengan jenis sambungan buttjoint, dan pada arus yang distandartkan maka dilakukan pengelasan. Hasil pengelasan dari beberapa speciment yang sama diperlakukan proses heat treatment pada temperatur yang berbeda; 7000C, 8000C, dan 9000C. Setiap speciment yang telah diberi perlakuan masingmasing dilakukan uji hardness. Adapun titik-titik yang diamati adalah bagian logam las, HAZ, dan juga logam induk. 


\subsection{Lokasi dan Waktu Penelitian}

Penelitian dilaksanakan pada bulan Juni sampai Desember 2016 di Laboratorium dan Bengkel Teknik Mesin Politeknik Negeri Ketapang.

\subsection{Alat yang Digunakan}

Adapun alat yang digunakan untuk menunjang penelitian ini adalah sebagai berikut:

1. Alat potong logam

2. Mesin Las

3. Elektroda

4. Penggores

5. Hardness Tester

6. Stopwatch

7. Kamera recorder

\subsection{Bahan}

Sedangkan bahan yang digunakan untuk menunjang penelitian ini adalah plat baja karbon rendah (low carbon steel) atau setara ST-37.

\section{Hasil dan Pembahasan}

Berdasarkan hasil pengujian, proses heattreatment pada logam dengan pendinginan yang sama (udara bebas) memberikan kecenderungan penurunan hardness. Namun demikian kecenderungan ini tidak lantas menjadi hal yang buruk pada kemampuan suatu logam (baja) namun semakin meningkatkan ductility yang berdampak pada sifat mampu mesin dan daya serap energi atau kemampuan terhadap impak. Sedangkan fenomena HAZ dan logam induk relatif sebanding terhadap heat treatment yang dilakukan atau mempunyai kecenderungan berharga sama yakni mengalami penurunan ketika temperatur dinaikan. Berikut secara grafik diperlihatkan perbandingan data masing-masing proses;

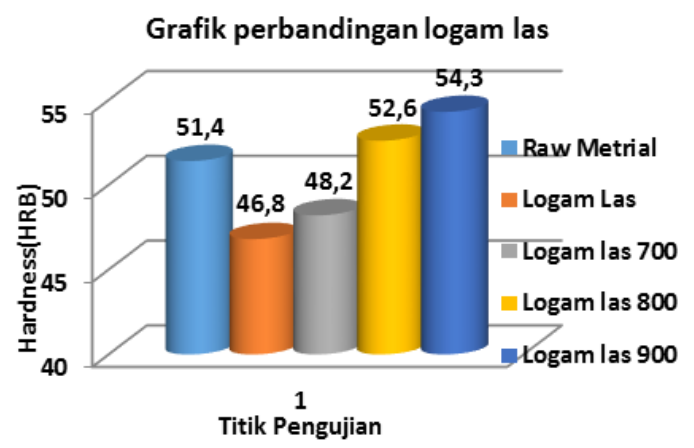

\section{Gambar 1. Perbandingan Raw Material dan} Logam Las Antara Suhu $700^{\circ} \mathrm{C}, 800^{\circ} \mathrm{C}, 900^{\circ} \mathrm{C}$

Pada gambar 3.1 diatas memperlihatkan hasil perbandingan antara raw material tanpa perlakuan panas, logam las dan $\mathrm{HAZ}$ pengaruh heattreatment $700^{\circ} \mathrm{C}, 800^{\circ} \mathrm{C}, 900^{\circ} \mathrm{C}$. Dari data yang diperoleh dengan rerata yang dilakukan bahwa ketika proses pengelasan tanpa heattreatment dampak proses menyebabkan penurunan nilai kekerasan bila dibandingkan raw material (raw 51.4 HRB, logam las $46.8 \mathrm{HRB}$ ). Selanjutnya dengan peningkatan temperatur heattreatment nilai kekerasan logam las semakin meningkat bahkan melampaui nilai kekerasan raw material, hal ini mengindikasikan bahwa pada heattreatment terendah menetralisir regangan yang terjadi pada logam; sedangkan pada temperatur yang lebih tinggi pengerasan regangan semakin terbentuk akibat perbedaan naiknya temperatur heattreatment terhadap pendinginan (48.2 HRB, 52.6 HRB, 54.3 HRB).

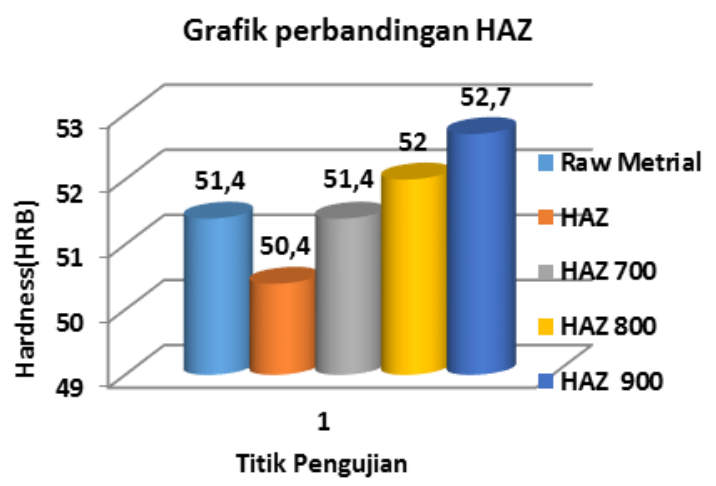

\section{Gambar 2. Spesimen Perbandingan Raw Material dan HAZ Antara Suhu $7^{\circ} 0^{\circ} \mathrm{C}, 800^{\circ} \mathrm{C}, 900^{\circ} \mathrm{C}$}

Gambar 3.2 diatas memperlihatkan fenomena HAZ mempunyai kesamaan seperti halnya logam las, namun dengan rata-rata sedikit lebih tinggi nilai kekerasan bila dibandingkan logam las. Hal tersebut menunjukan bahwa peningkatan temperatur juga memperbesar perbedaan pendinginan pada bagian HAZ sehingga ragangan panas semakin meningkat.

\section{Kesimpulan}

Penelitian tentang Pengaruh Perlakuan Temperatur Pemanasan Pada Hasil Pengelasan Metode SMAW Terhadap Hardness Logam Induk dan Logam Las memberikan kesimpulan sebagai berikut ;

1. Kekerasan raw material specimen teruji sebesar 51.4 HRB. Pada pengujian titik menunjukkan heat treatment temperatur $900^{\circ} \mathrm{C}$ memiliki nilai kekerasan logam las 54.3 HRB dan HAZ 52.7 HRB, pada temperatur heattreatment $800^{\circ} \mathrm{C}$ kekerasan logam las 52.6 HRB dan HAZ 52 HRB, sedangkan pada heattreatment $700^{\circ} \mathrm{C}$ kekerasan logam las 48.2 HRB dan HAZ 51.4 HRB. 
2. Hasil ini menunjukan bahwa peningkatan temperatur heat treatment menyebabkan perbedaan temperatur pada proses pendinginan semakin besar sehingga yang terjadi adalah kecenderungan pendinginan cepat; pendinginan cepat tersebut menyebabkan kekerasan material semakin meningkat.

\section{DAFTAR PUSTAKA}

Agarwal, R.L \& Tahil Manghnani, 1981. Welding Engineering. New Delhi: Khanna Publisher.

Amanto, Hari dan Daryanto. 2003. Ilmu Bahan. Jakarta: PT Bumi Aksara.

Ambiyar, dkk. 2008. Teknik Pembentukan Plat Jilid 1. DirektoratPembinaan Sekolah Menengah Kejuruan, Direktorat Jenderal Manajemen
Pendidikan Dasar dan Menengah, Departemen Pendidikan Nasional. Jakarta.

Basic Welding and Fabrication. New York: Mc Graw Hill Korb, Lawrence, et.al. 1987. Metals Handbook. Ohio: ASM International.

Cooke, F.C. 1951. Copra Manufactur (part). The Malayan Agricultural Journal XXIV.

Holman, J.P. 1988. Perpindahan Kalor. Penerbit Airlangga. Jakarta.

Surdia, Tata dan Kenji Chijiwa. 1984. Pengetahuan Bahan Teknik. Jakarta: PT Pradnya Paramita. 